\title{
Financial Administration Assistance In UMKM
}

\author{
Neny Tri Indrianasari \\ Department of Accounting, STIE Widya Gama Lumajang \\ indriana85@gmail.com
}

\begin{tabular}{lll}
\hline Submission : & Review : & Publication : \\
$2^{\text {st }}$ January 2020 & $13^{\text {th }}$ January 2020 & $28^{\text {th }}$ February 2020 \\
\hline
\end{tabular}

\begin{abstract}
Abstrak
This Community Service Activity is expected to provide the following outcomes for partners understanding partners in financial management, implementation of financial reports in accordance with SAK EMKM. The implementation of this Community Service (PKM) activity is carried out using the lecture, tutorial and discussion methods. Based on the results of the implementation of activities that have been carried out, there are several things that can be concluded from this Community Service activity, namely a. The training that was carried out was able to increase the desire to learn more deeply about financial recording activities in particular and increase the ability to do business in general. b. Training participants are able to explain and understand basic accounting concepts, accounting cycles and accounting information systems, c. The training participants still have a lot to learn and practice in preparing financial reports based on SAK EMKM.
\end{abstract}

\section{Keywords : Financial, Administration, UMKM}

\section{INTRODUCTION}

UMKM and cooperatives as business actors like it or not must be ready and anticipate this development. Data from the Central Statistics Agency (BPS) in 2017, the total number of UMKM in Indonesia is almost 60 million UMKM. Of this number, $98.74 \%$ were micro businesses, then around $1.15 \%$ were small business actors and $0.10 \%$ were medium enterprises. One thing that distinguishes this type of business is in terms of turnover. It is said that large businesses have an annual turnover of more than IDR 50 billion with assets of more than IDR 10 billion. Medium-sized enterprises are businesses with annual turnover of IDR 2.5 billion to IDR 50 billion with assets of IDR 500 million to IDR 10 billion. Small businesses are there businesses with a turnover of between Rp. 300 million to Rp. 2.5 billion with assets of Rp. 50 million to Rp. 500 million. Meanwhile, micro businesses have a turnover of up to Rp. 300 million per year with assets of up to Rp. 50 million. From this data, micro businesses have the largest number. However, there are still a lot of human resources from these micro business actors that must be improved. Many of these business actors have not paid attention to financial bookkeeping issues.

MSMEs face various obstacles or problems caused by 1) low education 2) lack of understanding of information technology, and 3) constraints in preparing financial reports (Muchid, 2015). The more a business develops, such as to increase business funding, it is necessary to deal with parties outside the company, either the bank or other financial institutions. The bank / financial institution will usually require financial reports to see the feasibility of providing credit. With the growing business, it requires MSMEs to provide financial reports in accordance with applicable standards. 
Even though the number of MSME players is quite large and makes a large contribution to the national economy, most MSMEs experience difficulties in developing their business. In general, the problems faced by MSMEs include access to capital, marketing, business and financial management, legal and taxation aspects. Financial management is one of the important aspects for the progress of companies, especially MSMEs. This is because the perpetrators are faced with HR problems. Financial management can be done through accounting, although in this case the standards used are basic and simple. Accounting is a systematic process for producing financial information that can be used for decision making for its users.

As long as MSMEs still use money as a transaction tool, accounting is needed by MSMEs. The existence of financial / accounting reports will provide several benefits for MSME actors, including: (a) MSMEs can find out the company's financial performance, especially the level of business and capital turnover; (b) UMKM can find out, sort and differentiate between business finances and owner finances; (c) MSMEs can find out the position of cash flows both sources and uses; (d) UMKM can make proper budget planning; (e) MSMEs can calculate taxes; and (f) MSMEs can find out the cash flow during a certain period.

Many MSME players manage their businesses on the basis of inadequate capabilities, especially aspects of financial management without having a basic knowledge or skills regarding business management and good financial management. It is not uncommon for businesses to only be run by relying on makeshift records and instinct and experience. The aspects of business management which include business planning, organizing, implementing, and controlling business are something that is rarely considered. In fact, this is a very vital and very important aspect in building and developing a business because the continuity of MSMEs is judged by its financial performance benchmarks.

Many MSME players find it difficult to use accounting in their business activities. This is due to limited manpower and abilities and the absence of guidelines or books that can be used as a reference for learning to manage MSME finances. There are no books currently circulating that focus on the financial management of MSMEs in Indonesia. Besides there are no books that specifically discuss transactions in MSMEs, many UMKM players are reluctant to read books because of their limited educational background.

Based on these problems, it is necessary to hold training activities for MSME players in managing finances using accounting. The training program offered is in the form of simple accounting training for MSMEs. The accounting taught is simple accounting that is adjusted to the conditions in MSMEs but does not deviate from existing standards and regulations. This training is intended for SMEs in Photocopy Services.

We know the difficulty of SME partners, namely obtaining capital, one of which is because they do not know how to prepare financial reports that can be provided to bank creditors. From several studies, SMEs have low quality financial reports Sri Mulyani (2014) stated that the quality of the financial reports made by MSMEs is low, so for parties related to and in contact with the interests of MSMEs (such as banking, the Ministry of Tax) in order to encourage MSMEs to provides great financial reports. Research by Rizki and Sylvia (2012) states that the results of research from respondents totaling 50 MSMEs in Depok who were the samples in their research showed that in fact the quality of MSME financial reports had no effect on the amount of credit received by MSMEs, this was due to the low quality of MSME financial reports so that banking still doubt the relevance and reliability of the quality of its financial reports. 
From some of these studies, it is stated that SMEs do have problems in making their business financial reports. One of the reasons for the difficulty of developing MSMEs is the inability of MSMEs to access credit, which is due to the unavailability of complete accounting information for MSMEs and because of not optimal accounting practices in MSMEs. For this reason, in order to develop MSMEs and create feasible, bankable, accountable and profitable MSMEs, the participation of the government and society is urgently needed in encouraging the application of accounting practices in MSMEs appropriately, implementing and sustainably (Nedsal et al. 2013). Teti Rahmawati and Okatviani (2017) the results of their research with UKM in Kuningan, West Java stated the need for socialization and training in financial reporting according to ETAP standards.

Based on the evaluation results from direct observation of people who have MSMEs in Karangsari Village, the main problems faced by them in starting and managing a business are as follows: a. Lack of understanding of financial statements. b. Not able to separate between personal and business financial records. c. The understanding of report analysis is still low.

\section{IMPLEMENTATION METHODS}

The implementation of this Community Service (PKM) activity is carried out using the lecture, tutorial and discussion methods. The stages of implementing this service activity are as follows:

a. Lecture method. Participants are given insight into the importance of financial management in starting and running a business. The first step was conducted through the 1.5 hour lecture method.

b. Tutorial Method. Training participants are given material on the preparation of financial reports, including income statements, reports on changes in capital, balance sheets. This material is presented in the form of a tutorial accompanied by exercises / case studies. The second step was held for 5 hours.

c. Discussion Methods. The training participants are given the opportunity to discuss problems related to the business they are already running or things they would like to ask to start a business. The third step was held for 1.5 hours.

In addition to steps 1,2 , and 3 above, mentoring activities will be carried out to compile business financial reports for 8 hours with a schedule of adjusting the target audience so that the total number of community service hours is met 16 hours.

\section{RESULTS AND DISCUSSION}

The training on the first day of Saturday, March 142020 went well. The first material given is the factors that cause the growth and progress of MSMEs to be obstructed, one of which is the problem of human resources and financial management knowledge and the solution by providing an introduction or introduction to accounting. The speaker explained the importance of accounting for MSMEs. Partners do not understand the function of accounting, even partners think that accounting is a complicated, difficult, troublesome, time consuming field. This first material is filled with strengthening the importance of accounting for small businesses (MSMEs).

After obtaining an agreement on the concept of MSMEs, it is continued with the financial reporting function for the entity. After the material on the concept of UMKM was completed, it continued with the second material regarding MSME accounting transactions. In this session, partners were asked to explain the partner's business operating activities. 
Furthermore, economic activities and non-economic activities are identified. Based on the identified economic activities, the accounting records are then carried out. The identified activities are initiated from starting a business (initial investment), purchasing transactions for raw materials, spending / spending, income / receiving, and others. After recording accounting transactions, the next material is compiling financial reports. As an exercise, partners are asked to make simple financial reports based on existing examples. This exercise ended at 3:00 p.m.

In the last session of this training, partners were asked to collect and record business transactions based on their respective fields that had been prepared. In this initial session the partners asked and discussed the transactions and records that had been made. This first session was quite time-consuming because the transactions and accounting records were discussed one by one. After the partners finish recording accounting transactions, the discussion continues to discuss the preparation of financial reports. In this last session partners were asked to prepare financial reports based on the accounting transactions they had made. The training activities ended at 15.00. Furthermore, assistance is provided to MSME accounting training partners independently in each place.

Partner Financial Report Results

Lamikro - Income Statement December 2019

Copy of Rezk-Q

\begin{tabular}{|c|c|c|c|}
\hline \multicolumn{4}{|c|}{ Pendapatan } \\
\hline Akun & Nama Akun & & Nilai \\
\hline 4020 & Pendapatan Jasa & & 1.638 .350 \\
\hline 4040 & Pendapatan Lain-lain & & 1.338 .675 \\
\hline \multirow[t]{2}{*}{4050} & Pendapatan Bunga Bank & & 0 \\
\hline & & Total Pendapatan & 3.409 .600 \\
\hline \multicolumn{4}{|l|}{ Beban } \\
\hline Akun & Nama Akun & & Nilai \\
\hline 6015 & Beban Kemasan & & 0 \\
\hline 6020 & Beban Pengiriman & & 0 \\
\hline 6030 & Beban Perlengkapan/ATK & & 0 \\
\hline 6040 & Beban Penjualan lain-lain & & 0 \\
\hline 6050 & Beban Gaji Karyawan & & 0 \\
\hline 6060 & Beban Komunikasi & & 0 \\
\hline 6070 & Beban Sewa & & 0 \\
\hline 6075 & Beban Listrik & & 0 \\
\hline 6076 & Beban Air & & 404.000 \\
\hline 6077 & Beban Telepon & & 0 \\
\hline 6078 & Beban PPh 21 Karyawan & & 0 \\
\hline 6079 & Beban Penyusutan \& Amortisasi & & 0 \\
\hline 6080 & Pajak NPWP & & 0 \\
\hline 6085 & Beban Piutang tak tertagih & & 0 \\
\hline 6090 & Beban Administrasi Bank & & 0 \\
\hline \multirow[t]{5}{*}{7000} & Beban lain-lain & & 255.000 \\
\hline & & Total Beban & 659.000 \\
\hline & & $\begin{array}{r}\text { Laba (rugi) Sebelum } \\
\text { Pajak }\end{array}$ & 2.750 .600 \\
\hline & & Biaya pajak penghasilan & 17.048 \\
\hline & & Laba (Rugi) setelah pajak & 2.733 .552 \\
\hline
\end{tabular}




\section{CONCLUSION}

Based on the results of the implementation of the activities that have been carried out, there are several things that can be concluded from this Community Service activity, namely:

a. The training carried out was able to increase the desire to learn more deeply about financial recording activities in particular and improve the ability to do business in general.

b. Training participants are able to explain and understand basic accounting concepts, accounting cycles and accounting information systems.

c. The training participants still have a lot to learn and practice in preparing financial reports based on SAK EMKM. follows:

Based on the activities that have been carried out, several suggestions can be made as

1. The existence of similar activities should always be held periodically so as to improve the skills and independence of MSMEs.

2. Additional time for practice in preparing financial statements based on SAK ETAP so as to increase the capacity of human resources in preparing financial reports.

\section{REFERENCES}

Bachmid, F. S. (2017). Pelatihan Akuntansi Berbasis Sistem Informasi Akuntansi. Jurnal Dharma Bakti Ekuitas: Vol. 01 No. 02

Ikatan Akuntan Indonesia. (2017). Pernyataan Standar Akuntansi Keuangan (PSAK). Jakarta. Santoso, I. R. (2018). Pelatihan Kewirausahaan Bagi Pelaku UMKM Di Kelurahan Biyonga Kecamatan Limboto Kabupaten Gorontalo. Gorontalo : Universitas Negeri Gorontalo. Satyarini, R. (2013). Pengabdian bagi Pelaku Usaha di Sekitar Unpar. Bandung: Jurnal Lembaga Penelitian dan Pengabdian Masyarakat Universitas Katolik Prahayangan.

Sukmadewi, Y. D. (2017). Sosialisasi Legalitas Dan Manajemen Usaha Bagi Pelaku Usaha UMKM Di Kecamatan Pedurungan Kota Semarang. Semarang : UniversitasSemarang. 